16 a 18 de autubro de 2019 - Campinas | Brasil

\title{
O avanço do agronegócio na região do MATOPIBA: a violência no campo e a resistência das quebradeiras de coco babaçu no sul do Maranhão (MA)
}

\author{
Luna Peres Guimarães*, Vicente Eudes Lemos Alves.
}

\begin{abstract}
Resumo
A agricultura atual brasileira foi estruturada dentro da lógica de economia capitalista gerando conflitos sociais devido à modernização do campo, fruto da internacionalização da economia e das novas formas de monopólio na agricultura. Através da expansão do agronegócio sobre a fronteira agrícola do MATOPIBA, no bioma de cerrados, busca-se, neste trabalho, compreender a modificação do espaço local pelos grandes proprietários de terra e pelas empresas monopolistas hegemônicas mundiais e como as formas de violência contra as comunidades tradicionais se estabelecem, tendo como referência de análise o caso das quebradeiras de coco babaçu no sul do Maranhão, a partir do papel central das mulheres na organização do uso comunitário dos bens naturais da região.
\end{abstract}

\section{Palavras-chave:}

Quebradeiras de Coco Babaçu, Monocultivos Agroflorestais, Sul do Maranhão

\section{Introdução}

Com base no avanço do agronegócio no Brasil e a sua associação a uma ampla articulação entre capital nacional e estrangeiro e o próprio Estado nacional brasileiro (DELGADO, 1982), propôs-se realizar este estudo dos conflitos no campo gerados a partir da transformação da estrutura produtiva do agrário brasileiro, especialmente em regiões de expansão da fronteira agrícola (ALVES, 2015). Para a realização da pesquisa, optou-se pela Região Tocantina Maranhense como recorte geográfico a partir da organização política do MIQCB (Movimento Interestadual das Quebradeiras de Coco Babaçu). Portanto, busca-se à compreensão de suas formas de resistência à expansão dos monocultivos agroflorestais na região do MATOPIBA.

\section{Resultados e Discussão}

A partir da análise da formação do meio agrícola brasileiro e das relações econômicas e sociais envolvidas nessa dinâmica, compreende-se que o êxito deste setor ocorreu através da exploração de recursos minerais (PRADO JUNIOR, 1957) e depende da grande concentração da propriedade de terras numa base territorial necessariamente extensa, do baixo número de empreendedores e da grande disponibilidade de força de trabalho (PRADO JUNIOR, 1981) resultando na formação de empresas que possuem monopólio mundial através da associação entre grupos econômicos nacionais e estrangeiros (OLIVEIRA, 2016). De acordo com Elias (2015), as Regiões produtivas do agronegócio (RPAs) tornam-se os locais de maior investimento produtivo desta economia, o que mobiliza, por meio da dialética entre escalas locais, regionais e internacionais, regiões produzidas pelo agronegócio e que são especializadas e corporativas. Este processo ocorre gerando muitos conflitos entre os dois lados, com imposição da violência por esse capital sobre as populações locais e seus ambientes de reprodução da vida. A violência no campo sofreu processo de intensificação no século XXI no Brasil e está associada à concentração de poder e do monopólio da terra. O presente estudo concentrou-se na Região Tocantina Maranhense na qual a produção agrícola de arroz, principalmente na Estrada do Arroz, se estabeleceu através da concessão de créditos proporcionados por bancos públicos e incentivos fiscais, possibilitando o crescimento do desmatamento vista a necessidade de abertura de área para que a pecuária bovina e os cultivos de arroz pudessem expandir-se (ALVES, NÓBREGA, 2018). O MIQCB é uma organização política de mulheres que vivem em comunidades tradicionais que tem como prática de subsistência a extração do coco babaçu e é fruto da disputa pela permanência no território e pelo acesso livre aos babaçuais através da Lei do Babaçu Livre, que exige que todas as pessoas que necessitarem do coco possam entrar em qualquer propriedade para coletá-lo. Nota-se a importância dessas mulheres para a preservação do meio ambiente por meio da manutenção dos "olhos d'água" e do manuseio responsável da palmeira de coco babaçu, enunciando também críticas à produção ilegal de carvão vegetal que desmata babaçuais. (ALMEIDA; SHIRAISHI NETO; MARTINS, 2005).

\section{Conclusões}

A pesquisa evidenciou as formas de avanço do agronegócio sobre o cerrado e os consequentes conflitos no campo gerados pelo mesmo, além da compreensão dos mecanismos de resistência do MIQCB e suas ações para a permanência de direitos sobre a produção praticada por essas mulheres em um contexto de Região produtiva do agronegócio.

\section{Agradecimentos}

Agradeço meu orientador, Prof. D. Vicente Eudes Lemos Alves, minha família e ao CNPq pela concessão da bolsa que possibilitou a realização da pesquisa.

ALMEIDA, Alfredo Wagner Berno de; SHIRAISHI NETO, Joaquim; MARTINS, Cynthia Carvalho. Guerra Ecológica Nos Babaçuais. São Luís: Miqcb/balaios Typographia, 2005.

ALVES, V.E.L. (Org.). Modernização e regionalização dos cerrados do centro-norte do Brasil: oeste da Bahia, sul do Maranhão e do Piauí e leste de Tocantins. Rio de Janeiro: Consequência Editora, 2015.

NÓBREGA, Mariana Leal Conceição. Os novos desafios das populaces agroextrativistas na Amazônia diante da instalação da empresa Suzano Papel e Celulose na Região Tocantina Maranhense. Revista Espaço e Geografia, Brasília, v. 21, n. 1, p.3-43, mar. 2018.

ELIAS, Denise. Reestruturação produtiva da agropecuária e novas regionalizações no Brasil. In: ALVES, Vicente Eudes Lemos (Org.). Modernização e Regionalização nos Cerrados do Centro-Norte do Brasil: Oeste da Bahia, Sul do Maranhão e do Piauí e Leste de Tocantins. Rio de Janeiro: Consequência Editora, 2015. p. 25-45.

OLIVEIRA, Ariovaldo Umbelino de. A Mundialização da Agricultura Brasileira. São Paulo: Iãnde Editorial, 2016.

PRADO JUNIOR, Caio. A Questão Agrária. São Paulo: Editoria Brasiliense, 1981

Formação do Brasil Contemporâneo. São Paulo: Editoria

Brasiliense, 1957. 